\title{
Curriculum components of technology education within the Maltese National minimum curriculum from year 1999 to 2016
}

\author{
Sarah Pule' 1,2 (D)
}

Accepted: 17 May 2018 / Published online: 23 May 2018

(C) The Author(s) 2018

\begin{abstract}
Like many other countries the curriculum components and goals of technology education in Malta have experienced evolutionary changes. Changes in Malta occurred at a fast rate but were not always perceived to be in step with international trends, debates and research about technology curricula. This document analyses the text in Maltese National Minimum Curriculum documents in light of international progress about: (a) research trends, (b) the philosophy of technology and (c) technological concepts. The analysis of the documents was framed through: (a) a quantitative analysis of documents; and (b) a small scale survey. The quantitative analysis of all texts involved the use of software to generate the top ranking words and phrases from all texts. These were ranked and compared across all documents to evidence the trends of the documents in time. The survey involved asking participants to review the documents for specific arguments and filling in a questionnaire. The findings show that only recently has the Maltese curriculum of Design and Technology aligned itself to international trends and embraced a contemporary philosophy of technology. Within the Maltese texts describing technology education in 1999 and 2012, the key jargon emanating from international debates is considered largely absent and the perception given is that of a technology curriculum that was not driven by research but by tradition. The potential implication of this at present is the lack of understanding of a rationale for general technology education in schools and the nostalgia for a technology curriculum driven solely by vocational roots.
\end{abstract}

Keywords Maltese curriculum - Design and technology · Philosophy of technology · Goals of technology education - International research trends $\cdot$ Technological concepts

Sarah Pule'

sarah.pule@um.edu.mt

University of Malta, Msida, Malta

2 Mgarr, Malta 


\section{Introduction}

This work analyses past and present Maltese National Minimum Curricula for the subject of Design and Technology Education in light of three aspects: (a) keeping up to date with international research trends; (b) being guided by the contemporary philosophy of technology; and (c) incorporating major technological concepts. The research questions addressed are the following:

1. To what extent are the expectations of general technology education in the Maltese National Minimum Curriculum aligned with international research trends?

2. To what extent are the expectations of general technology education in the Maltese National Minimum Curriculum aligned with the current philosophy of Technology Education?

3. To what extent are the expectations of general technology education in the Maltese National Minimum Curriculum targeting the teaching and learning of major Technological Concepts?

The documents considered for analyses are the following: two Maltese national minimum curricular documents: (a) "Creating the Future Together" (Ministry of Education 1999) and (b) "A National Curriculum Framework for All" (Ministry for Education and Employment 2012) and two syllabi: (a) SEC 33, secondary syllabus of year 2008 (DTLC 2006) and (b) (LOF), Learning Outcomes Framework (Ministry for Education and Employment 2016a). This paper first offers a brief overview of research trends, a contemporary philosophy of technology and technological concepts before proceeding to the analysis of the Maltese documents.

\section{Research trends}

Technology education has matured considerably within the past 20 years as can be deduced from the various reviews of literature conducted by different authors. One of the earliest is that of Zuga (1997) who reviewed research in technology education prior to 1993. Her conclusion was that, at the time, the research in technology education was positivistic and myopic. It had a sole focus on curriculum content and disregarded issues of the effectiveness of technology education to reach educational goals for all learners. The topics of research simply looked towards "the training of boys for future placement in vocational education" (p. 214). Petrina (1998) expressed the view that technology education contained little regard to critical theory. Consequently, de Vries (2000) discovered that trends in technology education in the 1990s related mostly toward defining the subject with particular emphasis on design and problem solving. Lewis (1999) and Carr et al. (2005) stated that technology education research needed to be multidimensional and more learner outcome based.

In response to such critique of the developmental paths of technology education, a series of book reviews and papers targeting diverse topics was published. In later years we find works such as that of Middleton (2008) which presents research methods for technology education. Jones and de Vries (2009) subsequently published a comprehensive book that targets diverse themes within research development such as the nature and philosophy of technology, perceptions of technology, teaching, learning, assessment, and teacher 
education amongst others. Benson and Lunt (2011) focused on technology education in the primary years. Two years later, Jones et al. (2013) build upon the prior work of The International Handbook of Research and Development in Technology Education by Jones and de Vries (2009) and discuss again developments within similar themes such as the philosophy of technology, international developments in technology curricula, teaching, learning, assessment, teacher education, professional development and approaches to research. Recently, Williams (2013, 2016) presented two comprehensive chronological trends of research in technology education. In both his works he outlines the most frequent topics of research presented in various international conferences and respected journals of technology education and he comes up with a ranking of research topics from 2006 to 2013. According to his later work, the ranking of research topics is reported in 2016 as follows: (a) curriculum; (b) design; (c) STEM; (d) teaching; and (e) learning. The Maltese curricula will later be analysed for evidence of the research trends and debates outlined in Williams's work.

\section{Philosophy of technology}

The discussion that follows summarizes concepts and issues raised by the work of de Vries (2016b). Accordingly, the philosophy of technology is useful for educators because it can help with the following: (a) determining the content of a curriculum; (b) providing insights on how to construct teaching and learning situations; (c) providing a conceptual basis for proper understanding of technology; and (d) positioning the teaching of technology among other subjects.

The philosophy of technology is a relatively young discipline which has evolved significantly over time and has now distinguished itself quite clearly from the philosophy of science. In his seminal work, Mitcham (1994) identifies two main approaches which can be adopted to reflect about technology: (a) the humanities philosophy of technology and (b) the engineering philosophy of technology. In the first, the focus is on the relationship between technology and society. In the second, the focus is on technology itself, that is, its ontology, epistemology, methodology, teleology, ethics and aesthetics. de Vries (2016b) explains that in the early days of the philosophy of technology, philosophers typically did not have an engineering or scientific background and debates tended to gravitate toward the humanities aspect of technology. In recent years, philosophers of technology tend to have an engineering background and the engineering philosophy of technology has expanded considerably. One consequence of this was that a clearer picture of how technology can be conceptualised has emerged. Mitcham (1994) had identified the following four ways in which technology can be conceptualised which today still prove useful: (a) technology as artefact; (b) technology as knowledge; (c) technology as activity; and (d) technology as volition.

The first notion is that of conceptualising technology as artefact. This centres around the nature and processing of an artefact and if this can indeed be classified as being technological. The nature of technological artefacts can be: (a) physical, in that it describes its physical properties (e.g., a knife is sharp and made of metal) and (b) functional, meaning that it describes the potential fulfilment of a desired intention (e.g., a knife is used to cut cake). Furthermore, an artefact can be seen to possess diverse qualifying functions and thus have diverse aspects to it, for example, a spatial aspect, a psychic aspect, a social aspect, an aesthetic aspect, an economic aspect and a symbolic aspect to name but a few (de Vries 2016b). 
The second notion is to conceptualise technology as knowledge. The argument that technology is simply "applied science" has long been abandoned since it has been argued that scientific knowledge and technological knowledge have different features. While scientific knowledge searches for the truth, adequacy, effectiveness or efficiency are more characteristic of technology. While scientific knowledge is usually universal, technological knowledge is context specific. While science aims for abstraction and idealisation, technology deals with concrete reality in its full complexity. Technology is also seen to have a normative component that is absent in science. de Vries (2016b) illustrates this by arguing that a machine can fulfil a function well or badly, but one cannot say if an electron is good or bad. A useful taxonomy of the aspect of technological knowledge as listed by de Vries is shown in Table 1. A professional engineer or designer usually acquires much of these aspects of technological knowledge during his/her educational formation.

The third way of conceptualising technological knowledge is as actions or processes. Just as technological knowledge is seen to differ from scientific knowledge, so do technological problems differ substantially from scientific problems. Scientific problems usually involve considerable challenges to find relationships between variables. This is not easy, but the structure of the problem may be well defined as the variables in question may be known. Technological problems that involve design can be highly complex because the variables that need to be taken into consideration for a successful design may be unknown and a clear definition of the problem might not be available. The problem is usually underdetermined and before a design proposal can be made, the problem in itself needs to be carefully formulated. The technological process can be seen to involve three main phases: (a) design, (b) make and (c) use and assess. Design processes can be either rational or reflective. Rational design is knowledge driven and systematic much like the way mechanical or electrical engineers design products based on knowledge of the engineering sciences. Reflective design is looser and more art-driven, much like the way architects tend to design their realizations. Typically both design processes do not fall under the linear, simplistic idea of analysis, synthesis and evaluation. The design process is not linear and real designers typically tend not to readily follow step by step prescriptive procedures. Both types of design need to take into account factors such as the following to ensure the success of a design: scientific, technological, market, political, juridical and ethical (de Vries 2016b).

Technology making processes have evolved over time as the transformation of materials, energy and information. de Vries (2016b) classifies these ways as: (a)

Table 1 Knowledge types in technology (de Vries 2016b)

\begin{tabular}{ll}
\hline Knowledge of the physical nature & $\begin{array}{l}\text { Knowledge of the } \\
\text { functional nature }\end{array}$ \\
\hline Numerical & Psychic \\
Spatial & Logical \\
Kinematical & Developmental \\
Physical & Symbolic \\
Biotic & Social \\
& Economic \\
& Aesthetic \\
& Juridical \\
& Ethical \\
& Trust \\
\hline
\end{tabular}


tool production, (b) machine production and (c) automated production. The diversity between these lies in what or who is responsible for the transformation of the three resources. In tool production materials, energy and information are all tackled by the human being as in the use of a hand drill. In machine production materials and energy are tackled by a machine but the transformation of information is still done by a human as in operating a lathe or milling machine. In automated production materials, energy and information are all manipulated by a computer as in the use of a CNC machine or a $3 \mathrm{D}$ printer, although the programming is still done by a human at the current stage of development of these technologies.

Technological processes are also seen to involve usage and assessment of a product. These processes need to encompass a user plan which typically involves knowledge about who will use the product; what the user wants to do with the product, that is his/her intentions; his/her beliefs that such a product will satisfy one's intentions, and finally the actions of the user. These considerations explain why, for example, the user manual of a washing machine clearly states that pets should not be washed in the machine. This might challenge the beliefs of some potential users of the product and guide them toward correct usage of it, apart from legally safeguarding the manufacturing company for not giving comprehensive information on the product.

The fourth way of conceptualizing technology is volition. A useful definition of technology is:

The modification of the natural environment in order to satisfy perceived human needs and wants (ITEEA 2007, p. 7).

A classical hierarchy of needs and wants is that presented by Maslow (1987). Lowest on the hierarchy one finds the physiological needs. These are followed by safety needs, needs of belonging, esteem, and self-actualisation. Technology is employed at every level of such needs and at every level of these needs technological developers such as engineers and designers can face moral dilemmas. A few moral dilemmas listed by de Vries (2016b) can be found hereunder:

1. Consideration for safety versus economy.

2. Financial versus environmental constraints.

3. Consideration for privacy versus accessibility of data.

4. Designing products for military use.

5. Designing products for human enhancement versus human dignity.

6. Designing cheaper products with the consequence of increased risks.

7. Accountability and collective responsibility in case of the failure of a product.

Finding an appropriate design while facing such moral dilemmas technology developers could experience the need to employ approaches based on virtues, consequences or rules and duties. Technology users could also face such dilemmas. Perceiving technology as volition means attuning to the motivations behind actions with technological products and usually involves exploration of desires, emotions, attitudes and willingness as related to the product use (Heikkerö 2008). Knowledge and experience of ethical issues in technology is therefore key for the educational formation of both technology developers and technology users. 


\section{Technological concepts}

Every subject taught in a curriculum is usually justified by a set of fundamental or key concepts. For example, for mathematics education some important concepts would be: counting, number representation, patterns, dimension and coordinates, addition, subtraction, multiplication, division, linear growth and exponential growth, functions, etc. For science education some important concepts would be: organisation, cause and effect, absolute and relative scale, proportion and quantity, stability and change etc. (NGSS Lead States 2013). For language education important concepts include: listening and understanding, speaking and communicating, vocabulary development and grammatical accuracy. Such fundamental concepts are those key competencies which all educators hope that students will retain long after they have left school. Technology education has identified fundamental concepts and sub-concepts as presented in Table 2 as those key skills which a student should retain after experiencing formal education within technology education. The list is not comprehensive but has found considerable agreement by international experts in technology and engineering education (de Vries 2016b, 2018; Rossouw et al. 2011). Such technological concepts are sometimes also referred to as "engineering habits of mind" (Lucas et al. 2014a, b).

\section{Method and findings}

The analysis of this research involved a document analysis of two Maltese national minimum curricular documents: (a) "Creating the Future Together" (Ministry of Education 1999) and (b) "A National Curriculum Framework for All" (Ministry for Education and Employment 2012) and two syllabi: (a) SEC 33 syllabus of year 2008 (DTLC 2006) and (b) (LOF), Learning Outcomes Framework (Ministry for Education and Employment 2016a).

The document analysis was framed through: (a) a quantitative analysis of documents; (b) two interviews, which included a questionnaire; with veteran engineers, only one of whom was previously familiar with the documents concerned; and (c) a questionnaire administered to one senior Design and Technology teacher who was familiar with the documents.

The quantitative analysis of all texts involved the use of the software Textalyser (2004) to generate the top ranking single words from all texts. These were then ranked in descending order. The software was also used to generate the prominence of three word phrases from all documents. The curricular documents of year 1999 and 2012 yielded short lists of phrases. For the 1999 document there were fourteen relevant three word phrases, while for the 2012 document there were thirty-three relevant three word phrases. These were analysed individually through a manual classify and sort procedure to identify nouns from verbs.

The syllabi documents of year 2008 and 2016 are more detailed and lengthy and thus required a different approach to their quantitative analysis, since identifying the top-ranked phrases resulted in having irrelevant phrases or repetitions in the outcome. These texts were first cleaned from titles, headers and footers and then subjected to specific keyword searches through a text editor. The searches yielded the frequency of the specific keyword and also the phrases where the keyword was used in the documents. The context of the specific keyword was determined qualitatively by the researcher by grouping similar phrases 


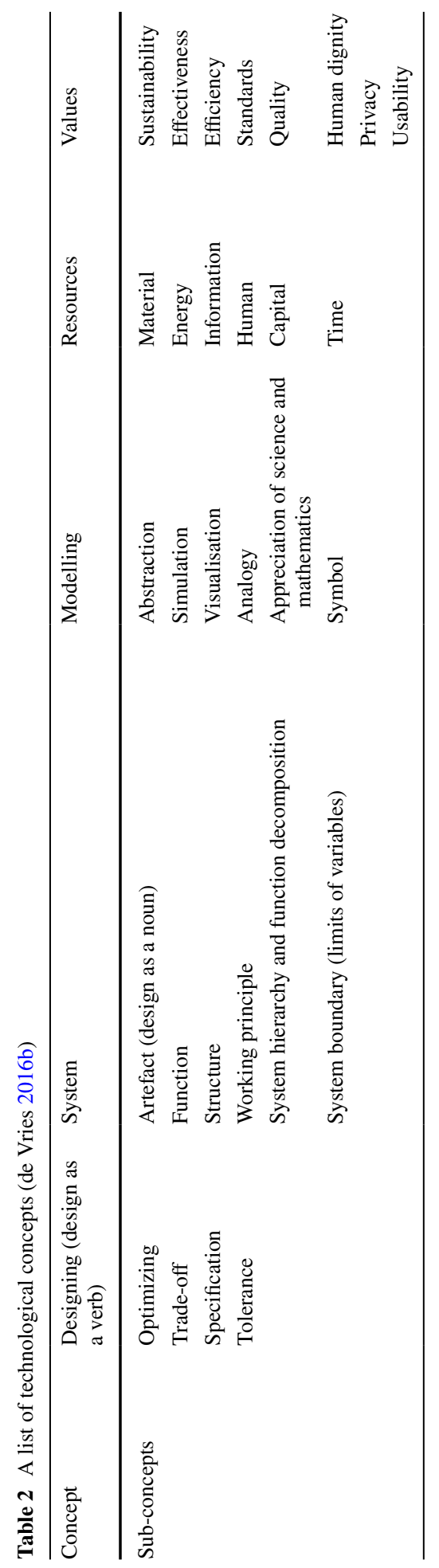


yielded by the software. The choice of specific keywords was based on the technological concepts presented in Table 2 and words with similar intent. To explore the variations of specific keywords within the documents, the frequency of each keyword, $f$, was compared by employing Eq. 1. The frequencies for each keyword were then ranked and plotted in descending order. A positive result for $f$ would indicate that a specific keyword was used more in the SEC33 2008 syllabus, while a negative result would mean that the specific keyword was utilised more in the LOF 2016 document.

$$
f_{\text {SEC33_2008 }}-f_{\text {LOF_2016 }}
$$

Although such text mining techniques are considered very basic, and are dependent on the relative power and performance of the software used, they can still offer insight about where the emphasis of documents might lie.

For the qualitative approach a small scale survey was conducted. The survey included interviews and a questionnaire as the main data collection instruments. Both these instruments were designed to extract data that would home in on the list of technological concepts in Table 2 within the documents under study. This provided a conceptual framework specifying a priori and in precise terms, the concepts sought, thus increasing the validity of the study (Cohen et al. 2000). The four point Likert scale used in the questionnaire, enabled only forced answers to the questions leaving no provision for a state of uncertainty. This was designed as such to enable the statistical analysis of the data for generating interrater correlations and ensure greater reliability of the outcome. The sample of participants classifies as a non-probability, purposive sample since easy accessibility, ethical clearance and time factors were prioritised at the time of reviewing the resources available for the survey.

Two veteran engineers with more than 30 years' experience in engineering and technology education participated in a $2 \mathrm{~h}$ guided interview during which they were requested to fill in a short questionnaire and comment on some themes which stemmed from the researcher's own observations of the documents. One senior Design and Technology teacher with more than 10 years experience was asked to fill in the questionnaire and comment freely on the documents through written means. The questionnaire involved nineteen items and participants were asked to rank the Maltese documents for each argument presented in the item. The questionnaire is presented in Table 3.

\section{Findings of quantitative text analysis: top ranking single words}

Table 4 shows the top ranking single words in all four documents. The variable $\mathrm{N}$ denotes the number of occurrences of each word. The row listing rank 1 shows that the year 1999 and 2012 documents cite the word "science" more than they cite the word "technology". The year 1999 document ranks "technology" as second only because it lumps the words "science and technology" together as a phrase and does not give an identity to either one of them. This is confirmed by the bar chart of Fig. 1 which shows that the prominence of the word "technology" when used separately from the word "science" is less than when they are used together. Phrases which use the words "science" or "scientific" dominate the document of year 1999 .

Table 4 also evidences that the word "design" features within the top ranks only from year 2008, and until year 2012 only ranked at the fifth position. The word "design" gained first rank with the document of year 2016. Table 4 also shows that the detail given in the documents varies. In year 1999 there is only mention of abstract nouns like "knowledge", "concepts" and "process". In year 2008 and 2012 there are nouns describing tangible items 
Table 3 Questionnaire presented to the participants who rated the Maltese documents

1 Rank (strongest $=1$, weakest $=4$ ) which curriculum/syllabus document best targets the recognition of an identity for technological knowledge as separate from that of scientific knowledge

2 Rank (strongest $=1$, weakest $=4$ ) which curriculum/syllabus document best portrays the picture that the attainment of technological knowledge is far more than just learning a defined set of manual skills

3 Rank (strongest $=1$, weakest $=4$ ) which curriculum/syllabus document best targets the physical attributes of technological artefacts (e.g. knives are sharp and made of metal)

4 Rank (strongest $=1$, weakest $=4$ ) which curriculum/syllabus document best targets the functional attributes of technological artefacts (e.g. knives are used to cut material)

5 Rank (strongest $=1$, weakest $=4$ ) which curriculum/syllabus document best targets the aesthetic/emotional attributes of technological artefacts (e.g. a chef's knife can be elegant, a soldier's knife can be scary)

6 Rank (strongest $=1$, weakest $=4$ ) which curriculum/syllabus document best targets the social, economic or ethical attributes of technological artefacts (e.g. a knife is a cheap and accessible technology that can be used to kill people)

7 Rank (strongest $=1$, weakest $=4$ ) which curriculum/syllabus document best targets rational design (e.g. design based on knowledge of the engineering sciences or mathematics)

8 Rank (strongest $=1$, weakest $=4$ ) which curriculum/syllabus document best targets reflective design (e.g. design based on looser constrains, more art driven)

9 Rank (strongest $=1$, weakest $=4$ ) which curriculum/syllabus document best targets the transformation of materials by tool production (e.g. hand tools and power tools where the human being controls the energy (brute force) needed and also the operation of the tool)

10 Rank (strongest $=1$, weakest $=4$ ) which curriculum/syllabus document best targets the transformation of materials by machine production (e.g. lathe and milling machine where the energy (brute force) is handled by the machine but the operation is still done by the human)

11 Rank (strongest $=1$, weakest $=4$ ) which curriculum/syllabus document best targets the transformation of materials by automated production (e.g. CNC or 3D printer where both energy (brute force) and operation is fully controlled by the machine)

12 Rank (strongest $=1$, weakest $=4$ ) which curriculum/syllabus document best targets the usage and assessment of a technological product (e.g. knowledge of user expectations and actions with the product)

13 Rank (strongest $=1$, weakest $=4$ ) which curriculum/syllabus document best targets the moral or ethical dilemmas which might be encountered when designing a technological product (e.g. safety versus economy, privacy versus accessibility of data, environmental constraints)

14 Rank (strongest $=1$, weakest $=4$ ) which curriculum/syllabus document best targets the technological concept of optimisation of a product

15 Rank (strongest $=1$, weakest $=4$ ) which curriculum/syllabus document best targets the technological concept of modelling through simulation of a product prior to manufacture

16 Rank (strongest $=1$, weakest $=4$ ) which curriculum/syllabus document best targets the technological concept of considering abstract entities such as time and energy as raw materials just as much as tangible materials like wood, metal and plastics

17 Rank (strongest $=1$, weakest $=4$ ) which curriculum/syllabus document best targets the technological concept of sustainability

18 Rank (strongest $=1$, weakest $=4$ ) which curriculum/syllabus document best targets the technological concept of efficiency

19 Rank (strongest $=1$, weakest $=4$ ) which curriculum/syllabus document best targets the technological concept of quality and reference to standards

such as "materials", and "components". In year 2016 the more tangible nouns include "components", "tools", "systems", "product" and "data". Table 4 also gives insight on the evolution of the verbs used. The document of year 1999 has no top tanking verbs. The verbs for the year 2008 document are "use", "know", "design" and "make" respectively. 


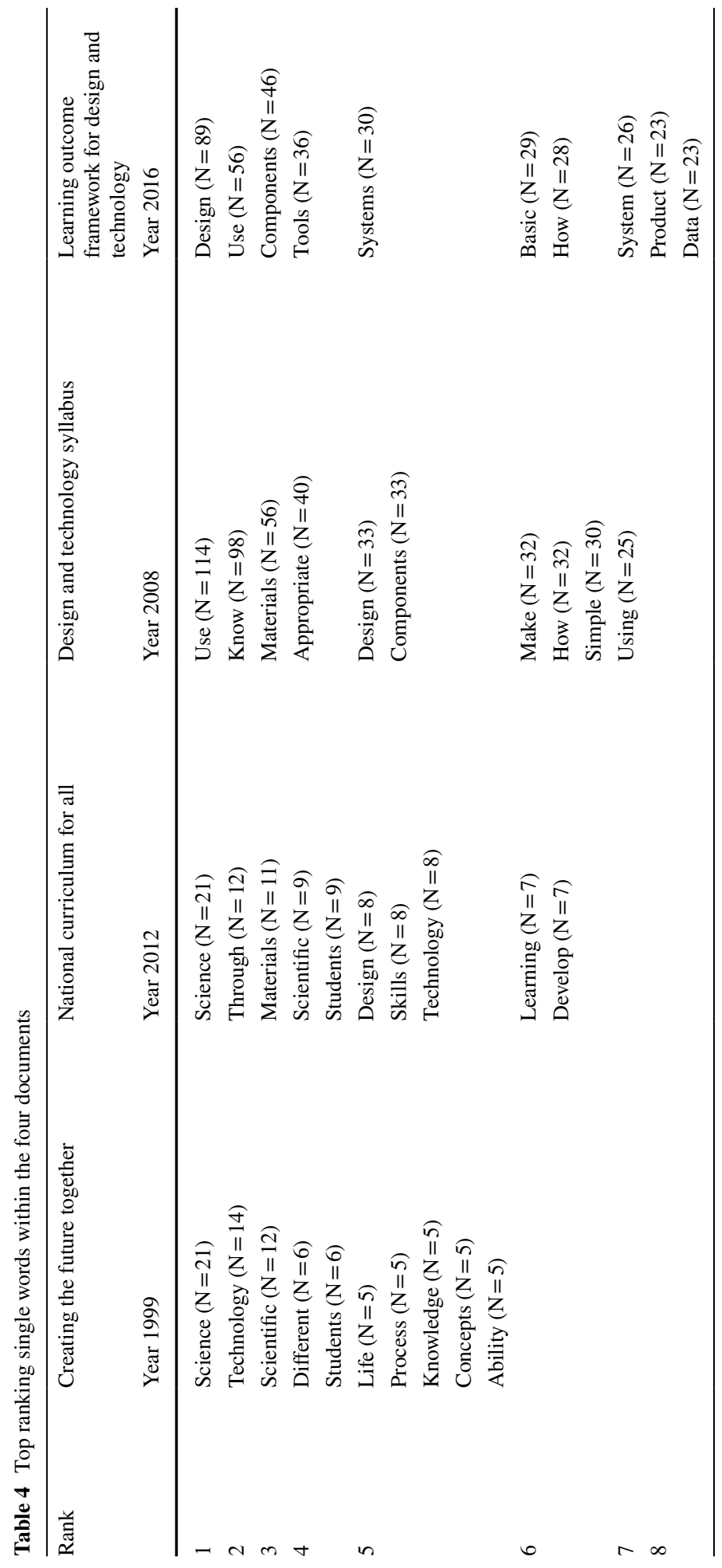


The prominence of top three-word phrases in Creating the Future together 1999

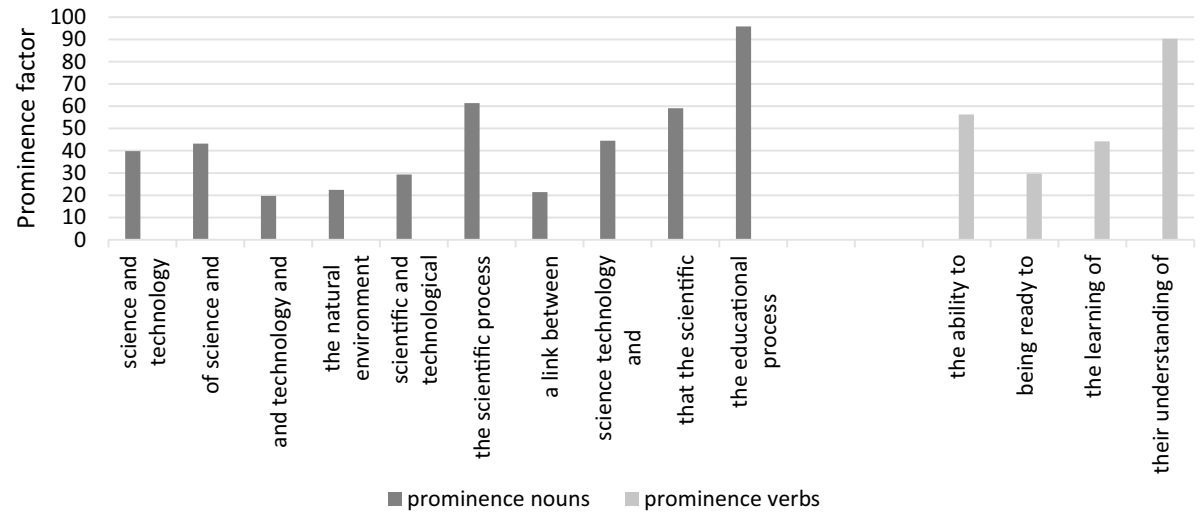

Fig. 1 The prominence of top three-word phrases in Creating the Future together 1999

Those for year 2012 are "design", "learning" and "develop", while the top ranking verbs for the document of year 2016 are "design" and "use". The respective rank sequence of such verbs indicates that a shift toward the "designing" rather than the "using" or just "knowing" occurred relatively recently.

\section{Findings of quantitative text analysis: prominence of three word phrases within the documents "Creating the Future Together" of year 1999 and "National Curriculum for All" of year 2012}

Figures 1 and 2 show the outcome of the top three word phrases from the manual analysis of the curricular documents of year 1999 and 2012. Both documents group together science and technology. The nouns for both figures show that until year 2012, the prominence of science over technology is clear. In Fig. 2 phrases such as "competence in science", "biological chemical physical", "science to daily" have most prominence. This might indicate

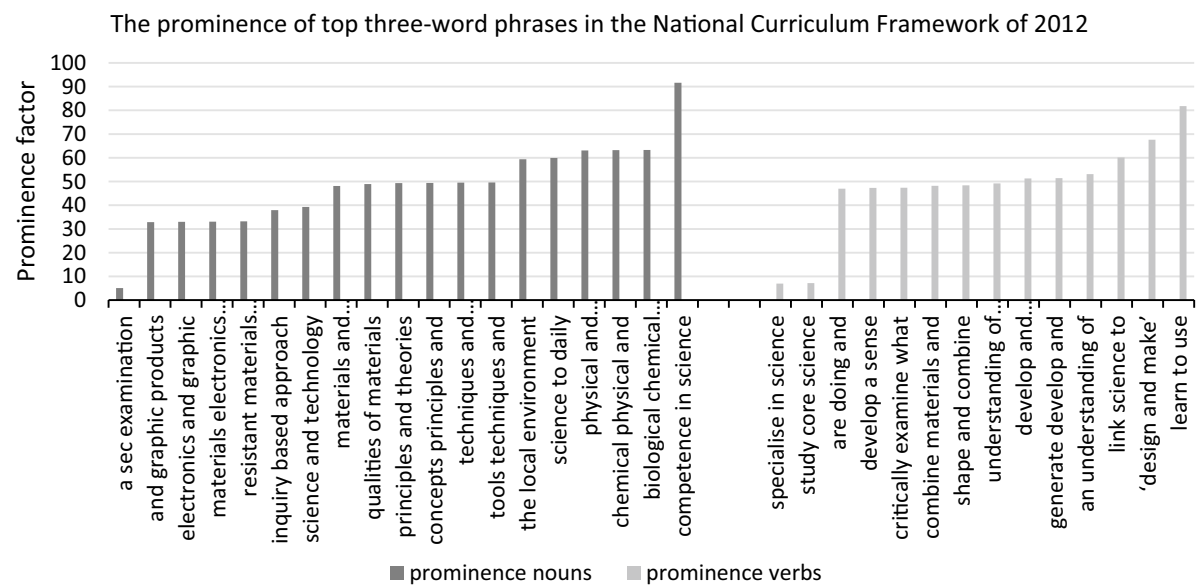

Fig. 2 The prominence of top three-word phrases in the National Curriculum Framework of 2012 
the existence of the perception that technology is simply applied science and therefore the prominence of the sciences would be justified by subscription to this perception. Within the verbs of the document of year 2012, the phrase "learn to use" is most prominent, with "design and make" as second most prominent. This might indicate a focus toward "usage" of technology rather than "innovative creation" of both the scientific and technological domains.

\section{Findings of quantitative text analysis: specific keyword search within the SEC33 syllabus of year 2008 and LOF of year 2016 documents}

The appendix compares the keyword searches of the two documents in question both in the frequency of the keywords and the context in which these are used. From the contexts of the keywords, it can be concluded that the LOF of year 2016 is the more mature document, since its contexts are wider and deeper than those of the SEC33 syllabus 2008 for the same set of keywords. From a quantitative point of view, the differences between the documents for each specific keyword can be viewed from Fig. 3. A comparison of the positive area under the curve to the negative area gives an indication of the collective difference for keywords between the documents. The areas under the curve were approximated by employing

DIFFERENCE IN WORD FREQUENCY: $f_{\left(S E C 33 \_2008\right)}-f_{(\text {LOF_2016) }}$

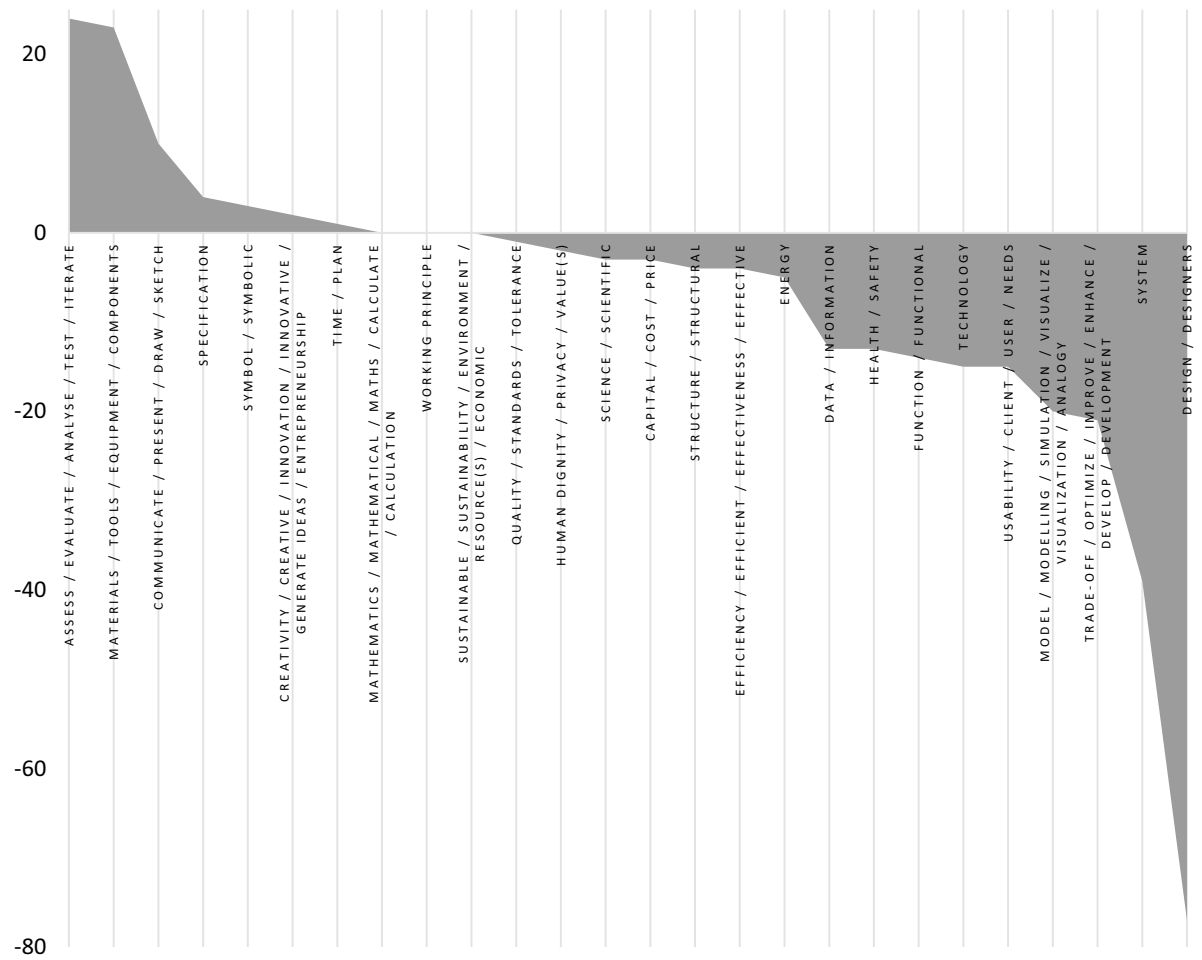

Fig. 3 A plot of the differences in the frequency of specific keywords for the SEC33 2008 and the LOF 2016 documents 
Table 5 Approximation to the areas of Fig. 3 using Reimann's sums method with a trapezoidal rule

\begin{tabular}{lc}
\hline Positive area & Negative area \\
\hline 55 & 210.5 \\
\hline
\end{tabular}

Reimann's sums method with a trapezoidal rule. Table 5 shows that the negative area is greater than the positive area, indicating a greater collective use of specific keywords in the LOF 2016 document.

\section{Findings of qualitative analysis: interviews and questionnaires with veteran engineers and senior design and technology teacher}

Table 6 shows the correlation coefficients obtained by analysing the questionnaire data through the Kendall tau- $b$ test on SPSS software. Based on this test, it can be concluded that all three participants and the researcher were in substantial agreement as to their views on the documents concerned and have ranked the documents in a similar fashion (minimum $\left.r_{\tau}=.553, \rho<.01\right)$.

The engineer who was previously unfamiliar with the documents was very passionate and emphasized the fact that the documents give the perception that technologists are people who "just make", who "follow instructions parrot-like fashion", who "are similar to robots". He said that the documents do not capture "the soul of technology, the intelligent aspect of designing, creating and visualising, but only focus on the making aspect, and this is also lifeless and devoid of the spirit of creativity". The second engineer agreed that the documents focused on the making aspect and that "designing features strongly only in the last document, although valid attempts at it are present in the SEC33 document of 2008". The senior Design and Technology teacher did not write extensive feedback but pointed out that it was tricky to compare the curricular documents with the syllabi since the latter held more detail by nature.

Table 6 Inter-rater correlations

Rater 1 Rater 2 Rater 3 Rater 4

\begin{tabular}{llllll}
\hline Kendall's tau_b & & & & \\
Rater 1 & Correlation coefficient & 1.000 & $\mathbf{. 9 4 8}^{* *}$ & $\mathbf{. 6 2 4}^{* *}$ & $\mathbf{. 8 4 9}^{* *}$ \\
& Sig. (2-tailed) & - & .000 & .000 & .000 \\
& N & 76 & 76 & 76 & 76 \\
Rater 2 & Correlation coefficient & 1.000 & $\mathbf{. 6 4 5}^{* *}$ & $\mathbf{. 8 6 5}^{* *}$ \\
& Sig. (2-tailed) & - & .000 & .000 \\
& N & 76 & 76 & 76 \\
Rater 3 & Correlation coefficient & & 1.000 & $\mathbf{. 5 5 3}$ \\
& Sig. (2-tailed) & & - & .000 \\
& N & & 76 & 76 \\
Rater 4 & Correlation coefficient & & & 1.000 \\
& Sig. (2-tailed) & & & - \\
N & & & 76 \\
\hline
\end{tabular}

**correlation is significant at the 0.01 level (2-tailed) 
The engineers' perspective is supported by the quantitative data. Figure 3 shows clearly that the keywords "design" and "designer" feature more prominently in the LOF 2016 document than in the SEC33 of 2008, while in the year 1999 and 2012 documents these words are practically non-existent. In contrast, phrases that contain keywords such as "materials, tools, equipment" feature more in the SEC33 of year 2008 than the LOF of year 2016. It seems plausible to speculate that the shift toward expectations of designerly thinking were present most strongly in the most recent document of year 2016, while earlier documents emphasized making skills over design skills.

The sections that follow highlight the themes which were discussed during the interviews with the engineers.

\section{National minimum curriculum (NMC) 1999: creating the future together}

The national minimum curriculum of year 1999 (Ministry of Education) marked an important milestone in the history of education in Malta because it was the first formal curriculum document. As listed in Table 7, the curriculum has 14 objectives, one of which, Objective 12, targets the "greater awareness of the role of science and technology in everyday life". Objective 12, like all the others in the document, is divided into three sections: knowledge, skills and attitudes. Although the overarching principles identified for technology education are valid and well-meaning, the veteran engineers agreed that references to technology education are woefully weak in many ways.

The NMC of 1999 is characterised by a severe dominance of science over technology to the extent that technology is unidentifiable from science. The verbs used to describe the desirable learning outcomes pertain almost exclusively to typical scientific behaviour and the targeting of scientific concepts. Thus such verbs as: classify, describe, observe, measure, analyse, gather and interpret data, formulate hypotheses and make generalisations are present. Terms such as "the scientific process", "the scientific language", "scientific knowledge", "branches of science" are also present (p. 49). Nevertheless, as pointed out by the engineers, parallel key terms about technology such as "the design process", "technological language or vocabulary", "technological knowledge", or "branches of technology" are

Table 7 The fourteen objectives of the Maltese National Minimum Curriculum of year 1999

\begin{tabular}{ll}
\hline Objective 1 & Self-awareness and the development of a system of ethical and moral values \\
Objective 2 & The development of citizens and a democratic environment \\
Objective 3 & Developing a sense of identity through creative expression \\
Objective 4 & Religious education \\
Objective 5 & Strengthening of gender equality \\
Objective 6 & Education on human sexuality \\
Objective 7 & Preparing educated consumers \\
Objective 8 & Media education \\
Objective 9 & Effective and productive participation in the world of work \\
Objective 10 & Education for leisure \\
Objective 11 & Wise choices in the field of health \\
Objective 12 & Greater awareness of the role of science and technology in everyday life \\
Objective 13 & Competence in communication \\
Objective 14 & Preparation for change \\
\hline
\end{tabular}


absent. Technological concepts such as designing, modelling, adopting a systems approach and considering values and resource utilization in a design are also absent. Where technology is mentioned, it is either in relation to information technology, tools, or the effect on society. This suggests that the philosophy of technology adopted in this document might only relate to viewing technology as artefact or as a production process, possibly limited to the digital technologies only. The perspective of viewing technology as volition is only slightly indicated by the mentioning of duties and ethics that scientists and technologists should observe. Brief reference is made to the natural environment only. In this curriculum the richness and detail of the philosophy of technology and technological concepts are largely absent. Thinking "scientifically and technically" is rather demeaned by implying that one should be able to "use audio-visual devices, use the computer and do odd jobs" (p. 75). This curriculum appears not to have been updated with research trends in technology education at the time, since in the 1990s international debates focused on defining subject topics such as technological design and problem solving, both of which are absent from the Maltese document of 1999.

\section{National minimum curriculum 2012: national framework for all}

The National Minimum Curriculum document of 2012 has its foundations on that of the year 1999, but it is a much more elaborate and detailed document. Within this document learning is divided into learning areas and cross-curricular themes, whereby Science and Technology are categorised as one learning area. Digital literacy is considered a crosscurricular theme. The document differentiates between the primary and secondary cycles within compulsory education as the junior years (years 3-6) and the secondary years (years 7-11). Within the secondary years there is a section describing a general vision for Vocational Education and Training (VET) subjects.

A general description of the Science and Technology learning area states that it:

$\ldots$ is directed to provide a clear understanding across the education cycles of how the process of inquiry and investigation leads to the development of solutions and their application. This is to be achieved through a pedagogical approach of "purposeful design and inquiry" that combines technological design with scientific inquiry, engaging students or teams of students in scientific inquiry situated in the context of technological problem-solving. (Ministry for Education and Employment, 2012, p. 8).

This description is considered a positive improvement with respect to what was written in year 1999, since some features pertaining to technology seem to be updated and described at par with those of science. Thus the term "purposeful design" features at par with "scientific inquiry". However, imbalances between science and technology still exist in favour of science. While the paragraph describing science (p. 35) alludes to "ethical issues", "sustainability" and "an understanding of changes caused by human activity and responsibility of individual citizens", the paragraph about technology states that "design and technology education primarily concerns design and make tasks" and puts emphasis only on "practical skills". Also, while the paragraph about science states that learners should "elaborate on explanations using appropriate scientific language techniques such as tables, charts and mathematical methods", for technology education no "appropriate language" is hinted. The paragraph about technology only states that the ideas generated and developed for chosen products need to be "communicated", but it does not offer guidance as to how this can be achieved. During the interviews the engineers argued how communication processes for 
technology are well known to overlap those for science as regards data representation (for example tables, graphs, diagrams etc.) and the modelling and manipulation of relationships for variables (e.g., mathematical equations and simulations). However, technology usually also comprises features from graphical languages such as engineering drawing. These do not usually feature as much in science, and not necessarily with the same detail. Such communication processes are not mentioned in this document.

\section{The junior years NMC 2012}

Section 03.3.2 (p. 51) describes aims of the Junior Years cycle and states that "literacy, numeracy and digital literacy are the foundations for further learning". The concept of "literacy" centres around these three pillars where technological literacy seems to equate to digital literacy. The learning area of science and technology for the junior years is further described (p. 53) in the document. While for science there is a mention of "scientific concepts and vocabulary", for technology, "technological concepts and vocabulary" are absent. While the texts suggests that learning science can be made "enjoyable" through "play" and use of "storytelling" and "drama", the paragraph on technology does not hint that this might be so even for learning technology. Apart from formative assessments like portfolios, assessment methods for science include "group and self-assessments", but for technology these are not mentioned. Instead, quoting for technology: "assessment is ongoing and ... often feedback is immediate as materials, tools, products and programs respond to what children are doing. A record of tasks/portfolio made can be kept" (p. 54). It seems that while learning technology the only feedback one expects to get is from the artefacts. This is certainly not aligned to arguments and recommendations from publications such as Kimbell (1997, 2005) and Garmire and Pearson (2006). Clearly, this approach misses the third phase that a technological process entails, that of usage and assessment of a product design.

The text on technology is characterised by the mentioning of materials rather than systems. The skills listed, "measure, mark out, cut, shape" refer to low level manual skills. The cognitive skill of visualization is absent as is the notion of designerly thinking (Cross 1982, 2007, 2011). The iterative nature of the design process (Bayazit 2004; Evbuomwan et al. 1996; Lawson 2006; Lewis 2005; Savage 2002; Savage and Sterry 1990a, b), the impetus and accomplishment of rigorous testing and optimisation or re-design are not described in detail but capped under the phrase "critically examine what they are doing and try to improve it" (p. 54). Once again, the targeting of complex technological concepts seems not to be expected from this curriculum.

The concept of having technological literacy as one of the pillars of education seems to be absent. This is in contrast to other countries which had debated comprehensively on the notion of technological literacy and its breadth and depth of meaning well before the year 2012 (Dyrenfurth and Kozak 1991; Gagel 1997, 2006; Lewis and Gagel 1992; Petrina 2000; Williams 2009). Standards for technological literacy were also being developed and refined well before the year 2012 (ITEA 1996, 2000, 2006; ITEEA 2003, 2007).

\section{The secondary years NMC 2012}

The section on science and technology competence for the secondary years can be found on page 59. Once again, the science section is much more elaborately described than the technology section. Scientific competence is described as being able to adopt an inquiry-based 
approach to learning. Technological competence is not defined. Quoting from p. 61, by studying science "students develop curiosity concerning natural phenomena leading them to question what they see and feel". The teaching of science is described as a vehicle that should develop "scientific thinking and understanding of higher order concepts, principles and theories in a holistic manner. Ethical, economic, social and moral issues contribute to a deeper understanding of science and its link to everyday life. This dimension helps students integrate knowledge from different learning areas and understand that science does not have a solution to all problem situations." The paragraph proceeds to describe that science is offered to all students in years 7 and 8, while its branches are optional from years 9 to 11 and all these lead to a secondary examination (MATSEC 2017a).

Within the paragraph on technology education, there is no mention of designerly thinking (Cross 1982, 2007, 2011), technological concepts and the philosophy of technology. Neither is there the expectation that students should develop curiosity about man-made systems. The engineers who were interviewed were surprised to find out that there is also no indication that, while science might not have "a solution to all problem situations", usually technology is able to circumvent problems and find a "fit for purpose" solution with contextual boundaries. The paragraph on technology only informs that the modules studied within the subject of Design and Technology are "Resistant Materials, Electronics and Graphic Products" without indicating how Design and Technology is studied from levels 7 to 11 . There is no information as to: (a) if D\&T is to be studied by all at level 7 and 8; (b) if it is offered as optional from level 9 to 11 ; and (c) if it leads to a secondary (SEC) examination. The interviewees found this lack of information both inexplicable and disappointing.

\section{SEC 33 syllabus, 2008}

The first formal qualification in Design and Technology awarded by the Matriculations and Secondary Education Certificates Examinations Board (MATSEC) in 2008 was the SEC 33 whose syllabus was based on a document written in year 2006 (DTLC). On page 5 of the introduction, Design and Technology is defined as a "vocationally oriented subject". The phrase, "the work in school should always reflect what is happening in industry", suggests that a narrow perspective of the rationale for technology education is adopted. It seems that education should always be reactive to the needs of industry, rather than those of the learners within a future society. The participant engineers considered this statement as contradictory to a vision of education that prioritizes research skills in technology, where, more often than not, a researcher must face the unknown, rather than emulate the present. Nevertheless, the syllabus aims (p. 16) encompass goals such as creative design, social, moral, economic and environmental issues, roughly hinting at the perspective of volition in the philosophy of technology. Each of the topics of study (Resistant Materials, Electronics, Food and Textiles) has sections defining designing skills, making skills, evaluating skills, knowledge and understanding, communication, and health and safety. The design process is described as having a linear structure. Communicating this design involves producing written information that is "legible with correct spelling, punctuation and grammar", drawing, sketching, use of colour and texture, use of ICT to "access, store and retrieve" information or present design ideas and working drawings as 2D or 3D models or simulations (p. 23). This emphasizes the reflective aspect of design. The approach to a design which is driven by mathematics is very shallow as illustrated in the appendix. Where language writing skills are involved, there is indication if a student should be helped or else should be allowed to write with minimum assistance. Other skills do not have such instructions attached to them, so it seems that differentiation between language and other 
skills is accentuated. The technological concepts discussed in "Technological concepts" section are largely absent, however, the request for a specification, simplistic modelling, visualisation and evaluation of a design do feature. The making processes for transformation of materials still focus on the aspect of (hand) tool production rather than machine or automated production.

The engineers agreed that in many ways, this document indicates that the philosophy adopted has encompassed more features from the philosophy of technology as discussed in "Philosophy of technology" section and there was an attempt at targeting some technological concepts, albeit in simplistic ways. Nevertheless, drawing on their extensive experience, they also agreed that the roots of vocational education still transpire from the detail of the document and it seems that the expectation for a vocational orientation of the subject, rather than a more general one, was the desired path for technology education at this stage in Malta.

\section{The learning outcomes framework (LOF), 2016}

The National Curriculum Framework of 2012 proposed a Learning Outcomes Framework throughout the years of compulsory schooling (Ministry for Education and Employment 2016a). This gave rise to the ESF 1.228, a project whose intent was to design the learning outcomes framework and associated Learning and Assessment Programmes for all levels of compulsory schooling. This project has been partially completed and the education system is expected to slowly transition into the demands of this framework.

Where technology education is concerned, the ESF 1.228 LOF has marked a very important milestone regarding the expectations from a curricular document. Although within the general description of the learning area of science and technology, the term "scientific literacy" prevails and "technological literacy" still does not appear, both the quantitative analysis and the interview discussions indicate that this document shows a marked improvement for the subject of Design and Technology within the secondary years, that is from Level 7 to 11 . Within the junior years of level 5 and 6, technology education is subsumed within science education and, although some aspects of technology are covered, the uniqueness of technology may not be evident. It is not known if debates about diversities between science and technology, and the nature of relationships between science and technology such as those offered by Cross et al. (1981) and Williams (2002) are being reviewed. Nevertheless, levels 7-11 breathe new life into the expectations from technology education. Based on the British guidelines by Morgan et al. (2013) who have classified Design and Technology as a general academic subject, levels 7-11 of the subject of Design and Technology have the subject foci identified in Table 8. Design and Technology is now compulsory for all learners at levels 7 and 8 .

Table 8 Subject Foci within ESF 1.228 learning outcome framework

\begin{tabular}{ll}
\hline 1 & Design, entrepreneurship and innovation \\
2 & Critique, implications and evaluation \\
3 & Data collection and interpretation \\
4 & Technology-materials and making \\
5 & Technology-systems and control \\
6 & Technology-graphics, communication \\
& and digital production \\
\hline
\end{tabular}


These subject foci infer the nature of a technological knowledge that stands unique from scientific knowledge, albeit being highly related. They embrace a wide definition of technology and accommodate a diversity of knowledge and skill types which can be taken at different levels of competence. Finally, in this curriculum one finds direct targeting of technological concepts and a philosophy of technology that is the most comprehensive from all prior Maltese curricula. This is evident from the text in that it contains phrases such as those in the following list. Here, amongst many of the learning outcomes similar to past curricula, the student should be able to:

1. Model verbally, visually, graphically, physically and digitally.

2. Consider a systems approach.

3. Forsee, plan and gain insight.

4. Evaluate a product against its function.

5. Think critically and pass judgements constructively.

6. Consider responsibilities for his/her design decisions.

7. Make use of research tools.

8. Represent systems in symbolic ways.

9. Model and simulate a prototype system.

10. Iterate to and from solutions and problems to refine a design proposal.

Clearly, the Learning Outcomes Framework of 2016 is the document which shows the greatest effort in the implementation of a contemporary philosophy of technology education. This curriculum appears to be the first Maltese technology curriculum which targets social reconstruction rather than manual skill development or preparation for a technological career. It would therefore be the first one which appreciates the intrinsic value of technology for education and also the first to be aligned to contemporary international research trends about technology education as a general, not vocational, subject in schools.

\section{Discussion}

Like other countries (Lewis 1993), technology education in Malta did not evolve without serious challenges. A brief historical account of how technology education has evolved in Maltese schools is given by Navarro and Pule' (2015) and shows that like many other countries, technology education has held strong vocational roots. The understanding of the goals of general technology education within the Maltese national minimum curriculum has evolved greatly in positive directions but there is still room for improvement when compared to the progress made by other countries. From the documents analysed, it can be concluded that prior to and including the year 2012, the Maltese curriculum was not rigorously up to date with research trends, did not embrace a comprehensive philosophy of technology and targeted only a small subset of technological concepts.

Up to the year 2013, work conducted by Williams (2013) indicates that the most frequent topics for research were: (a) design; (b) curriculum; (c) technological literacy; (d) thinking; and (e) teacher training and teaching. The Maltese curriculum of 1999 mentions none of these topics. That of 2012 just touches on the notion of design. It mentions three branches for curriculum content, but it missed completely the notion of technological literacy. The emphasis on the "doing" over the "thinking" is evident. Until the year 2016, the work of Williams (2016) indicated that apart from curriculum content, research trends 
reflected work on design, STEM and teaching and learning. As evidenced by the quantitative results of this study, the Maltese LOF of 2016 has improved much in defining the curriculum content and incorporating design as a fundamental concept, however it still needs to align itself to current research trends as regards how to embrace the STEM (or STEAM) philosophy and also possibly the pre-engineering philosophy as explained in the work of de Vries et al. (2016). Linkages to science and in particular, mathematics are still weak.

Regarding the reception of the philosophy of technology and the addressing of technological concepts, Maltese curricula and syllabi prior to and including the year 2012 can be considered as generally lacking international understanding and expectations demanded from technology education. With the LOF of 2016 technology education has finally gained an identity that is distinguishable from science education. It has evolved from being considered as a vocational specialisation to a general requirement for all learners. This has also helped to improve the perceived status of the subject. The LOF of 2016 indicates that the expectations of the Maltese curriculum are now aligned considerably better to a more comprehensive and contemporary philosophy of technology. There is evidence to show that both the humanities philosophy of technology and the engineering philosophy of technology are represented. The LOF of 2016 also offers opportunities to perceive technology as more than just "artefact making". Opportunities to perceive the definitions of technology as knowledge, process and volition also exist. Most importantly, the LOF of 2016 targets in a direct way the fundamental technological concepts at a modern, higher level than ever before. Indeed, if such a curriculum is implemented with valid and reliable success for all learners, Maltese citizens would be able to claim themselves technologically literate with pride.

The Maltese curriculum has indeed set its course on a better understanding of the goals of technology education and expectations from such a curriculum are therefore higher. A new syllabus based on the LOF of 2016 has been launched for year 2019 (MATSEC 2018). It is conjectured however, that the navigational route continues to be challenged by microperceptions rather than hermeneutic ones, that is, perceptions guided by what the eye can see rather than those that are based on explanations. It is unfortunately not uncommon to listen to arguments which justify the vocational classification of the subject of Design and Technology simply because it "includes manual skills", or uses equipment similar to that for traditional vocationally oriented courses. Dakers and de Vries (2009) described this as a condition of stasis or stagnation due to the dominant orthodoxy of procedural knowledge over conceptual knowledge. Indeed, for technology education to succeed as specified in the LOF of 2016, significant perceptual reform is required. Recent proposals that re-classify the subject of Design and Technology as a vocational subject (Ministry for Education and Employment 2016b, p. 6 footnote 10) do not augur well for technology education in Malta and only serve to suggest that certain proposals are more politically driven than educationally driven. de Vries (2016a) discusses how the reconceptualising and analysis of the content of the curriculum still does not give information on educational practice at the classroom level. Giving a good image of what technology education is will depend not only on the expectations of the curriculum but also on the agents employed to implement it, from policy makers, to support systems, to consultancy systems, to teacher educators and ultimately to teachers themselves. The fact that issues of curriculum content have somewhat settled in Malta does not mean that perceptions have changed significantly. It is nevertheless a good first step towards encouraging a transition. Useful evaluations of the past and predictions for the future may be accessed from works such as that of Barlex (2018) who discusses essential conditions which must be met before success can be claimed for a Design and Technology curriculum. These include the availability of sustained and high 
quality in-service training for teachers, realistic ambitions for the school scenarios, and effective communication and understanding of the philosophy and rationale of the subject, especially with key stakeholders. Indeed Barlex warns against misinterpretations whereby Design and Technology is considered as a vocational option for the few, or a subject which is to be presented to those less academically able.

\section{Recommendations}

Maltese general technology education needs to develop a coherent, continuous vision and framework for technology education that spans from early childhood to post-secondary education. The technology curriculum needs to reflect and keep up with the major debates within contemporary research. The first step toward this goal could be to develop a vision document that explicates and aligns decisions with curriculum theory as suggested by Herschbach (1989), Zuga (1989) and Lewis and Zuga (2005) while also addressing issues critiqued by Petrina (1994) and others such as (a) what should be taught in a technology curriculum and why?, (b) can disparate rationales co-exist in harmony?, (c) how should technological knowledge be organised for learning?, (d) is the technical model the only way to plan a technology curriculum? (e) what other models exist and what benefits could they offer?. A second step would be to look into other countries' positive efforts in aligning towards a contemporary philosophy of technology. Good examples are found in documents such as ITEEA (2003, 2007). A locally grown Maltese document should offer a comprehensive definition of technology based on a contemporary philosophy of technology. One that includes but is not limited to the digital technologies. The definition should state clearly and explicitly the diverse roles served by technologically oriented curricular subjects such as SEC 33 Design and Technology (MATSEC 2017b) and SEC 37 vocational Engineering Technology (MATSEC 2017c) and link these to a theoretical interpretation that characterizes technological knowledge. This could be a valuable exercise to evaluate the curricular content and pedagogical methods used for these subjects and diversify them accordingly so that they complement each other rather than compete with each other.

A locally grown Maltese vision document should offer arguments that go beyond the classification of technology education as academic or vocational (O'Sullivan 2013; Williams 2015). As discussed by Cross (2007), “design in general education is not primarily a preparation for a career, nor is it primarily a training in useful productive skills for 'doing and making' industry" (p. 21). Design education should be defined in terms of its intrinsic educational values. Hence it should concentrate on (a) addressing the understanding and implementation of a contemporary philosophy of technology, (b) how technological concepts are taught and learnt and how to develop engineering habits of mind as defined by de Vries (2016b) and Lucas and Hanson (2016) and Lucas et al. (2014a), (c) how to foster human development through technology and engineering education (Barak and Hacker 2011) and (d) what is the future of technology education in Malta in light of developments in research trends (de Vries 2018; Williams and Barlex 2017; Williams et al. 2015). The document should give guidance as to how to develop a technological literacy in Malta that equips learners to participate in a democratic society while also offering knowledge, skills and values relevant for the future workplace. 
Open Access This article is distributed under the terms of the Creative Commons Attribution 4.0 International License (http://creativecommons.org/licenses/by/4.0/), which permits unrestricted use, distribution, and reproduction in any medium, provided you give appropriate credit to the original author(s) and the source, provide a link to the Creative Commons license, and indicate if changes were made.

\section{Appendix}

Specific keyword search ranked in descending order with respect to the difference in frequencies between documents

\begin{tabular}{|c|c|c|c|c|c|}
\hline & & $\begin{array}{l}\text { SEC } 33 \text { D\&T syl- } \\
\text { labus }\end{array}$ & & LOF for D\&T & \\
\hline & & Year 2006 & & Year 2016 & Difference \\
\hline Keyword searched & $f_{\text {SEC 33_2008 }}$ & Context used & $f_{\text {LOF_2016 }}$ & Context used & $f_{\text {SEC33_2008 }} f_{\text {LOF_2016 }}$ \\
\hline $\begin{array}{l}\text { Assess/evaluate/ } \\
\text { analyse/test/ } \\
\text { iterate }\end{array}$ & 43 & $\begin{array}{l}\text { Risk assessment/ } \\
\text { analyse and } \\
\text { evaluate product } \\
\text { against speci- } \\
\text { fication using } \\
\text { criteria/evaluate a } \\
\text { range of familiar } \\
\text { products/ana- } \\
\text { lyse situation to } \\
\text { identify need and } \\
\text { problem/analyse } \\
\text { more than one } \\
\text { material/analyse } \\
\text { a mechanism/ } \\
\text { test and evaluate/ } \\
\text { carry out tests/ } \\
\text { testing of circuits } \\
\text { on breadboard/ }\end{array}$ & 19 & $\begin{array}{l}\text { Assess suitability, } \\
\text { benefits, proce- } \\
\text { dures/risk assess- } \\
\text { ment/Evaluate, } \\
\text { reflect and refine/ } \\
\text { evaluate features } \\
\text { against specifica- } \\
\text { tions/evalu- } \\
\text { ate and argue } \\
\text { concerns/analyse } \\
\text { influences/ana- } \\
\text { lyse a system, } \\
\text { an ecological } \\
\text { footprint, design } \\
\text { proposals, design } \\
\text { performance, } \\
\text { simulate, debug, } \\
\text { model and ana- } \\
\text { lyse circuits/use } \\
\text { data analysis for } \\
\text { strategic decision } \\
\text { making/testing } \\
\text { procedures/test } \\
\text { for quality/plan } \\
\text { for testing/iter- } \\
\text { ate to and from } \\
\text { solutions/ }\end{array}$ & 24 \\
\hline
\end{tabular}




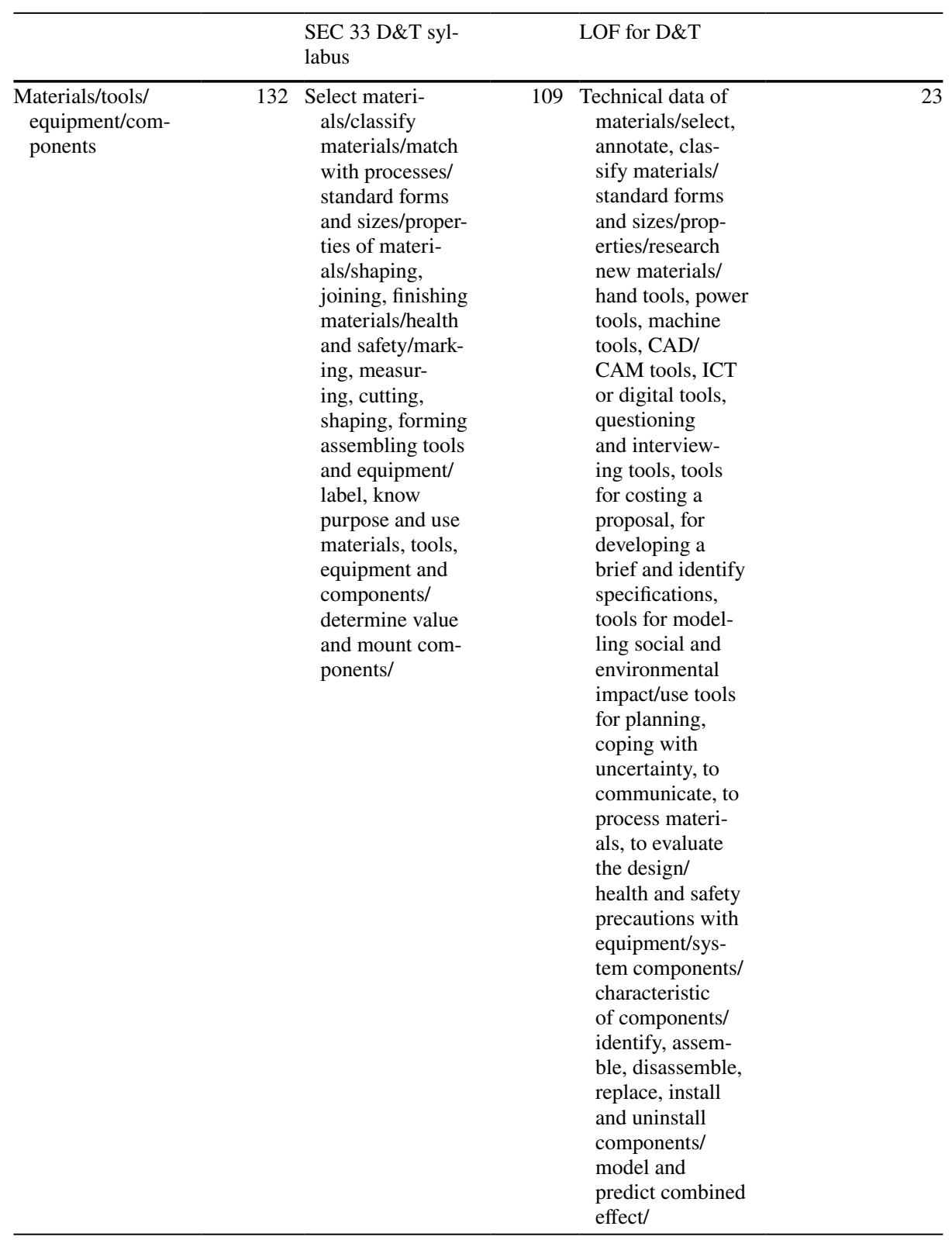




\begin{tabular}{|c|c|c|c|c|c|}
\hline & & $\begin{array}{l}\text { SEC } 33 \text { D\&T syl- } \\
\text { labus }\end{array}$ & & LOF for D\&T & \\
\hline $\begin{array}{l}\text { Communicate/pre- } \\
\text { sent/draw/sketch }\end{array}$ & 54 & $\begin{array}{l}\text { Communicate ideas } \\
\text { (freehand sketch- } \\
\text { ing, isometric, } \\
\text { oblique projec- } \\
\text { tions, nets, first } \\
\text { and third angle } \\
\text { orthographic } \\
\text { projections)/2D, } \\
\text { 3D presentation/ } \\
\text { present working } \\
\text { drawing/present } \\
\text { a block diagram/ } \\
\text { present design } \\
\text { idea/drawing to } \\
\text { enable manu- } \\
\text { facture/draw } \\
\text { circuits/ }\end{array}$ & 44 & $\begin{array}{l}\text { Communication } \\
\text { with clients, } \\
\text { users, designers/ } \\
\text { communicating } \\
\text { using colour and } \\
\text { texture/communi- } \\
\text { cate and interpret } \\
\text { graphically and } \\
\text { verbally/commu- } \\
\text { nicate the design } \\
\text { and its research/ } \\
\text { communicate } \\
\text { with lettering } \\
\text { and annotations/ } \\
\text { communicate } \\
\text { health and safety } \\
\text { precautions/com- } \\
\text { municate using } \\
\text { symbols/collect } \\
\text { and portray data } \\
\text { that communi- } \\
\text { cates the design/ } \\
\text { represent systems } \\
\text { in various ways/ } \\
\text { present appealing } \\
\text { and marketable } \\
\text { design proposals/ } \\
\text { draw 2D, 3D, } \\
\text { orthographic } \\
\text { views, graphical } \\
\text { symbols, tessel- } \\
\text { lations, surface } \\
\text { geometry nets, } \\
\text { working parts } \\
\text { of the design, } \\
\text { organisational } \\
\text { diagrams/draw- } \\
\text { ing digitally/ }\end{array}$ & 10 \\
\hline Specification & 12 & $\begin{array}{l}\text { Write specification/ } \\
\text { test and evaluate } \\
\text { against specifica- } \\
\text { tion/ }\end{array}$ & 8 & $\begin{array}{l}\text { Derive specifica- } \\
\text { tion/evaluate } \\
\text { against produc- } \\
\text { tion specification } \\
\text { and against user } \\
\text { response/ }\end{array}$ & 4 \\
\hline Symbol/symbolic & 12 & $\begin{array}{l}\text { Safety symbols/ } \\
\text { SI units and } \\
\text { symbols/symbols } \\
\text { to illustrate/ }\end{array}$ & 9 & $\begin{array}{l}\text { Graphical symbols/ } \\
\text { relate symbols to } \\
\text { physical features/ } \\
\text { draw and apply } \\
\text { symbols/recog- } \\
\text { nize symbols/ } \\
\text { graphical, verbal } \\
\text { and symbolic } \\
\text { ways/ }\end{array}$ & 3 \\
\hline
\end{tabular}




\begin{tabular}{|c|c|c|c|c|c|}
\hline & & $\begin{array}{l}\text { SEC } 33 \text { D\&T syl- } \\
\text { labus }\end{array}$ & & LOF for D\&T & \\
\hline $\begin{array}{l}\text { Creativity/creative/ } \\
\text { innovation/inno- } \\
\text { vative/generate } \\
\text { ideas/entrepre- } \\
\text { neurship }\end{array}$ & 6 & $\begin{array}{l}\text { Generate and } \\
\text { record ideas/ }\end{array}$ & 4 & $\begin{array}{l}\text { Importance of } \\
\text { creativity and } \\
\text { entrepreneur- } \\
\text { ship in the } \\
\text { development and } \\
\text { progress of soci- } \\
\text { ety/creative, rel- } \\
\text { evant, informed } \\
\text { designs/creativity } \\
\text { risk and failure/ } \\
\text { entrepreneurship } \\
\text { role/ }\end{array}$ & 2 \\
\hline Time/plan & 22 & $\begin{array}{l}\text { Resistor-capacitor } \\
\text { timing/555 Timer } \\
\text { ic/time constant } \\
\text { formula/relation- } \\
\text { ship of time with } \\
\text { frequency/time } \\
\text { plans and work } \\
\text { schedules/ }\end{array}$ & 21 & $\begin{array}{l}\text { Limitations of } \\
\text { resources/555 } \\
\text { Timer ic/plan- } \\
\text { ning implementa- } \\
\text { tion/planning } \\
\text { safety/planning } \\
\text { a system/plan- } \\
\text { ning to cope } \\
\text { with uncertainty/ } \\
\text { planning for } \\
\text { evaluation/plan- } \\
\text { ning for assembly } \\
\text { for disassembly/ } \\
\text { plan view of an } \\
\text { object/ }\end{array}$ & 1 \\
\hline $\begin{array}{l}\text { Mathematics/ } \\
\text { mathematical/ } \\
\text { maths/calculate/ } \\
\text { calculation }\end{array}$ & 7 & $\begin{array}{l}\text { Gear ratio/combi- } \\
\text { nation of resis- } \\
\text { tors/power/ }\end{array}$ & 7 & $\begin{array}{l}\text { Circuit parameters/ } \\
\text { graphical and } \\
\text { mathematical } \\
\text { methods/ }\end{array}$ & 0 \\
\hline Working principle & 0 & & 0 & & 0 \\
\hline $\begin{array}{l}\text { Sustainable/ } \\
\text { sustainability/ } \\
\text { environment/ } \\
\text { resource(s)/eco- } \\
\text { nomic }\end{array}$ & 12 & $\begin{array}{l}\text { Issues of pollution, } \\
\text { waste, manage- } \\
\text { ment, economic } \\
\text { use/environment } \\
\text { friendly/eco- } \\
\text { nomic benefits }\end{array}$ & 12 & $\begin{array}{l}\text { Sustainable energy } \\
\text { sources/ethi- } \\
\text { cal principles/ } \\
\text { socially just } \\
\text { practices/design } \\
\text { sustainability into } \\
\text { products/limita- } \\
\text { tion of resources/ } \\
\text { resource deple- } \\
\text { tion/resource } \\
\text { availability/glo- } \\
\text { balisation/access } \\
\text { to economic } \\
\text { factors/economic } \\
\text { priorities/ }\end{array}$ & 0 \\
\hline
\end{tabular}




\begin{tabular}{|c|c|c|c|c|c|}
\hline & & $\begin{array}{l}\text { SEC } 33 \text { D\&T syl- } \\
\text { labus }\end{array}$ & & LOF for D\&T & \\
\hline $\begin{array}{l}\text { Quality/standards/ } \\
\text { tolerance }\end{array}$ & 9 & $\begin{array}{l}\text { Finishing of prod- } \\
\text { uct/judge quality } \\
\text { by how it looks, } \\
\text { its performance, } \\
\text { its function/safety } \\
\text { standards/toler- } \\
\text { ance of materials/ } \\
\text { tolerance of } \\
\text { resistors/ }\end{array}$ & 10 & $\begin{array}{l}\text { Quality control/ } \\
\text { quality assurance/ } \\
\text { quality finishing } \\
\text { techniques/qual- } \\
\text { ity information } \\
\text { graphics/high } \\
\text { quality functional } \\
\text { products/stand- } \\
\text { ardised com- } \\
\text { ponents/stand- } \\
\text { ardised form of } \\
\text { materials/ }\end{array}$ & $\overline{-1}$ \\
\hline $\begin{array}{l}\text { Human dignity/pri- } \\
\text { vacy/value(s) }\end{array}$ & 4 & $\begin{array}{l}\text { Values of compo- } \\
\text { nents in a circuit/ } \\
\text { values of end } \\
\text { users/ }\end{array}$ & 6 & $\begin{array}{l}\text { Values of compo- } \\
\text { nents in a design/ } \\
\text { value and context } \\
\text { of the solution/ } \\
\text { ethical values/ } \\
\text { rating parameter } \\
\text { values/ }\end{array}$ & -2 \\
\hline Science/scientific & 0 & & 3 & $\begin{array}{l}\text { Interdisciplinary } \\
\text { approach/ }\end{array}$ & -3 \\
\hline Capital/cost/price & 1 & $\begin{array}{l}\text { Primary and sec- } \\
\text { ondary sources of } \\
\text { energy/ }\end{array}$ & 4 & $\begin{array}{l}\text { Costing of design } \\
\text { proposals/costing } \\
\text { of manufacturing } \\
\text { processes/price } \\
\text { for consumer } \\
\text { if product is } \\
\text { prototype or mass } \\
\text { produced etc./ }\end{array}$ & -3 \\
\hline Structure/structural & 0 & & 4 & $\begin{array}{l}\text { Define design } \\
\text { within a struc- } \\
\text { ture/structured } \\
\text { design goals/ } \\
\text { consumer } \\
\text { market structure/ } \\
\text { mechanical or } \\
\text { aesthetic struc- } \\
\text { ture/ }\end{array}$ & -4 \\
\hline $\begin{array}{l}\text { Efficiency/efficient/ } \\
\text { effectiveness/ } \\
\text { effective }\end{array}$ & 2 & $\begin{array}{l}\text { Measuring and } \\
\text { marking out/ }\end{array}$ & 6 & $\begin{array}{l}\text { Efficiency and pro- } \\
\text { ductivity/use of } \\
\text { material/effective } \\
\text { communication/ } \\
\text { effective attempts } \\
\text { to reconcile data/ }\end{array}$ & -4 \\
\hline Energy & 1 & $\begin{array}{l}\text { Different sources } \\
\text { of energy/mains, } \\
\text { power supply } \\
\text { units/ }\end{array}$ & 6 & $\begin{array}{l}\text { Propose and use } \\
\text { different energy } \\
\text { sources/discuss } \\
\text { sustainable } \\
\text { sources/evaluate } \\
\text { concerns about } \\
\text { energy depletion/ }\end{array}$ & -5 \\
\hline
\end{tabular}




\begin{tabular}{|c|c|c|c|c|c|}
\hline & & $\begin{array}{l}\text { SEC } 33 \text { D\&T syl- } \\
\text { labus }\end{array}$ & & LOF for D\&T & \\
\hline Data/information & 16 & $\begin{array}{l}\text { Datasheet/clear } \\
\text { legible informa- } \\
\text { tion with correct } \\
\text { spelling/access, } \\
\text { store and retrieve } \\
\text { information/ } \\
\text { relevant written } \\
\text { information/ } \\
\text { graphical and } \\
\text { text form/ }\end{array}$ & 29 & $\begin{array}{l}\text { User data from } \\
\text { surveys/data } \\
\text { collection and } \\
\text { recording tools/ } \\
\text { technical data/ } \\
\text { analyse, select, } \\
\text { interpret data/ } \\
\text { present data in } \\
\text { accordance to } \\
\text { ethical require- } \\
\text { ments/datasheets/ } \\
\text { Big data/share } \\
\text { data/reconcile } \\
\text { conflicting data/ } \\
\text { visualise a design } \\
\text { from data/picto- } \\
\text { rial informa- } \\
\text { tion/statistical } \\
\text { information/ } \\
\text { documentation } \\
\text { of information/ } \\
\text { essential and } \\
\text { quality informa- } \\
\text { tion/ }\end{array}$ & -13 \\
\hline Health/safety & 21 & $\begin{array}{l}\text { Ensure health and } \\
\text { safety/safety } \\
\text { standards/con- } \\
\text { sider safety when } \\
\text { selecting materi- } \\
\text { als and finishes/ } \\
\text { safety guards/ } \\
\text { follow safety } \\
\text { symbols/safety in } \\
\text { terms of product } \\
\text { maintenance and } \\
\text { function/ }\end{array}$ & 34 & $\begin{array}{l}\text { Provisions for } \\
\text { health and safety/ } \\
\text { precautions, } \\
\text { implications/ } \\
\text { lab practices/use } \\
\text { of equipment/ } \\
\text { adopt embedded } \\
\text { health and safety } \\
\text { practices and } \\
\text { take responsibil- } \\
\text { ity for them/ } \\
\text { interpret health } \\
\text { and safety data } \\
\text { about equipment } \\
\text { and materials/ } \\
\text { personal protec- } \\
\text { tive equipment/ }\end{array}$ & -13 \\
\hline Function/functional & 20 & $\begin{array}{l}\text { Achieve speci- } \\
\text { fied functional } \\
\text { results/ }\end{array}$ & 34 & $\begin{array}{l}\text { Predetermined } \\
\text { function/func- } \\
\text { tional diagrams/ } \\
\text { function usabil- } \\
\text { ity/functional } \\
\text { innovation/func- } \\
\text { tional standards/ }\end{array}$ & -14 \\
\hline Technology & 2 & $\begin{array}{l}\text { Design and } \\
\text { technology labo- } \\
\text { ratories/ }\end{array}$ & 17 & $\begin{array}{l}\text { Technology indus- } \\
\text { try/manufactur- } \\
\text { ing technology/ } \\
\text { laboratories/envi- } \\
\text { ronmental and } \\
\text { cultural impact } \\
\text { on society/ }\end{array}$ & -15 \\
\hline
\end{tabular}




\begin{tabular}{|c|c|c|c|c|c|}
\hline & & $\begin{array}{l}\text { SEC } 33 \text { D\&T syl- } \\
\text { labus }\end{array}$ & & LOF for D\&T & \\
\hline $\begin{array}{l}\text { Usability/client/ } \\
\text { user/needs }\end{array}$ & 4 & $\begin{array}{c}\text { Needs and values } \\
\text { of end users/ }\end{array}$ & 19 & $\begin{array}{l}\text { Usability and } \\
\text { access factors/ } \\
\text { roles of clients } \\
\text { users and design- } \\
\text { ers/user data/ } \\
\text { user response/ } \\
\text { user evaluation/ } \\
\text { user interface/ } \\
\text { target users/user } \\
\text { interaction/past } \\
\text { influence of users } \\
\text { on design/ }\end{array}$ & -15 \\
\hline $\begin{array}{l}\text { Model/modelling/ } \\
\text { simulation/visual- } \\
\text { ize/visualization/ } \\
\text { analogy }\end{array}$ & 12 & $\begin{array}{l}\text { Modelling } \\
\text { materials/2D } \\
\text { and 3D models } \\
\text { and simulations/ } \\
\text { circuit simula- } \\
\text { tions/use ICT for } \\
\text { simulation/ }\end{array}$ & 32 & $\begin{array}{l}\text { Modelling materi- } \\
\text { als/modelling } \\
\text { software pack- } \\
\text { ages/interactive } \\
\text { models/gain } \\
\text { insight from } \\
\text { models/manipu- } \\
\text { late and describe } \\
\text { models/3D } \\
\text { models/business } \\
\text { models/social, } \\
\text { environmental } \\
\text { and cultural } \\
\text { models/circuit } \\
\text { simulation/ }\end{array}$ & -20 \\
\hline $\begin{array}{l}\text { Trade-off/optimize/ } \\
\text { improve/enhance/ } \\
\text { develop/develop- } \\
\text { ment }\end{array}$ & 12 & $\begin{array}{l}\text { Improve appear- } \\
\text { ance/skills/ideas/ } \\
\text { develop work } \\
\text { plan/ }\end{array}$ & 33 & $\begin{array}{l}\text { Optimize func- } \\
\text { tion/improve } \\
\text { efficiency/perfor- } \\
\text { mance/learning/ } \\
\text { enhance com- } \\
\text { munication/ideas/ } \\
\text { gain insight/ } \\
\text { forsee/develop- } \\
\text { ment of human } \\
\text { society/ }\end{array}$ & -21 \\
\hline System & 17 & $\begin{array}{l}\text { Block diagram/ } \\
\text { input-process- } \\
\text { output/ }\end{array}$ & 56 & $\begin{array}{l}\text { Systems approach/ } \\
\text { modularity of } \\
\text { systems and sub- } \\
\text { systems/input- } \\
\text { process-output/ } \\
\text { system organisa- } \\
\text { tion/system } \\
\text { representation/ } \\
\text { complementarity } \\
\text { of systems/ }\end{array}$ & -39 \\
\hline
\end{tabular}




\begin{tabular}{|c|c|c|c|c|}
\hline & & $\begin{array}{l}\text { SEC } 33 \text { D\&T syl- } \\
\text { labus }\end{array}$ & LOF for D\&T & \\
\hline Design/designers & 38 & $\begin{array}{l}\text { Brief/process/ } \\
\text { ideas/design and } \\
\text { make/design } \\
\text { and technology } \\
\text { laboratories/ }\end{array}$ & $\begin{array}{l}15 \text { Brief/decisions/ } \\
\text { ideas/criteria/ } \\
\text { problem/pro- } \\
\text { posal/ }\end{array}$ & -77 \\
\hline
\end{tabular}

\section{References}

Barak, M., \& Hacker, M. (Eds.). (2011). Fostering human development through engineering and technology education. Rotterdam: Sense Publishers.

Barlex, D. (2018). Design and technology in England: An ambitious vision thwarted by unintended consequences. In M. J. de Vries (Ed.), Handbook of technology education (pp. 109-124). Cham: Springer.

Bayazit, N. (2004). Investigating design: A review of forty years of design research. Design Issues, 20(1), 16-29. https://doi.org/10.1162/074793604772933739.

Benson, C., \& Lunt, J. (Eds.). (2011). International handbook of primary technology education: Reviewing the past twenty years. Rotterdam: Sense Publishers.

Carr, M., McGee, C., Jones, A., McKinly, E., Bell, B., Barr, H., \& Simpson, T. (2005). The effects of curricula and assessment on pedagogical approaches and on educational outcomes. Literature review. Wellington, New Zealand: Ministry of Education. Retrieved from http://www.educationcounts.govt. nz/_data/assets/pdf_file/0003/9273/The-Effects-of-Curricula-and-Assessment.pdf. Accessed 21 May 2018.

Cohen, L., Manion, L., \& Morrison, K. (2000). Research methods in education (5th ed.). London: RoutledgeFalmer.

Cross, N. (1982). Designerly ways of knowing. Design Studies, 3(4), 221-227.

Cross, N. (2007). Designerly ways of knowing. Basel: Birkhäuser Verlag GmbH.

Cross, N. (2011). Design thinking: Understanding how designers think and work. London: Berg Publishers.

Cross, N., Naughton, J., \& Walker, D. (1981). Design method and scientific method. Design Studies, 2(4), 195-201.

Dakers, J. R., \& de Vries, M. J. (2009). Perceptions of technology and technology education. In A. Jones \& M. J. de Vries (Eds.), International handbook of research and development in technology education (pp. 201-210). Rotterdam: Sense Publishers.

de Vries, M. J. (2000). Can we train researchers and teachers to make a team? Win-win strategies in technology education. In Paper presented at the 1st Biennial international technology education research conference, Gold Coast, Australia.

de Vries, M. J. (2016a). Reconceptualising technology through education. In M. J. de Vries (Ed.), Teaching about technology: An introduction to the philosophy of technology for non-philosophers (pp. 91-100). Cham: Springer.

de Vries, M. J. (2016b). Teaching about technology: An introduction to the philosophy of technology for non-philosophers. Cham: Springer.

de Vries, M. J. (Ed.). (2018). Handbook of technology education. Cham: Springer.

de Vries, M. J., Gumaelius, L., \& Skogh, I.-B. (Eds.). (2016). Pre-university engineering education. Rotterdam: Sense Publishers.

DTLC. (2006). Design and technology syllabus. Malta: Department of Technology in Education, Design and Technology Learning Centre.

Dyrenfurth, M. J., \& Kozak, M. R. (Eds.). (1991). Technological literacy. Glencoe: Macmillan/ McGraw-Hill.

Evbuomwan, N. F. O., Sivaloganathan, S., \& Jebb, A. (1996). A survey of design philosophies, models, methods and systems. In Proceedings of the institution of mechanical engineers, part b: journal of engineering manufacture (Vol. 210(4), pp. 301-320). Retrieved from http://journals.sagepub.com/doi/ pdf/10.1243/PIME_PROC_1996_210_123_02. Accessed 21 May 2018.

Gagel, C. W. (1997). Literacy and technology: Reflections and insights for technological literacy. Journal of Industrial Teacher Education, 34(3), 6-34. 
Gagel, C. W. (2006). Towards an authentic technological literacy. Journal of Industrial Teacher Education, 43(4), 69-75.

Garmire, E., \& Pearson, G. (Eds.). (2006). Tech tally: Approaches to assessing technological literacy. Washington: The National Academies Press.

Heikkerö, T. (2008). How to address the volitional dimension of the engineer's social responsibility. European Journal of Engineering Education, 33(2), 161-168.

Herschbach, D. R. (1989). Conceptualizing curriculum change. Journal of Epsilon Pi Tau, 15(1), 19-28.

ITEA. (1996). Technology for all Americans: A rationale and structure for the study of technology. International Technology Education Association. Retrieved from http://scholar.lib.vt.edu/TAA/Taa_tech.pdf. Accessed 30 October 2017.

ITEA. (2000). Standards of technological literacy: Content for the study of technology. International Technology Education Association. Retrieved from http://www.iteaconnect.org/Publications/publications.htm. Accessed 20 October 2007.

ITEA. (2006). Technological literacy for all: A rationale and structure for the study of technology. International Technology Education Association. Retrieved from http://www.iteaconnect.org/Publications/publicatio ns.htm. Accessed 22 October 2007.

ITEEA. (2003). Advancing excellence in technological literacy: Student assessment, professional development, and program standards. International Technology and Engineering Educators Association. Retrieved from https://www.iteea.org/File.aspx?id=78445\&v=1476043b. Accessed 7 May 2017.

ITEEA. (2007). Standards for technological literacy: Content for the study of technology third edition. International Technology and Engineering Educators Association. Retrieved from https://www.iteea.org/File. aspx $? \mathrm{id}=67767 \& \mathrm{v}=\mathrm{b} 26 \mathrm{~b} 7852$. Accessed 7 May 2017.

Jones, A., Buntting, C., \& de Vries, M. J. (2013). The developing field of technology education: A review to look forward. International Journal of Technology and Design Education, 23(2), 191-212.

Jones, A., \& de Vries, M. J. (Eds.). (2009). International handbook of research and development in technology education. Rotterdam: Sense Publishers.

Kimbell, R. (1997). Assessing technology: International trends in curriculum and assessment, UK, Germany, USA, Taiwan, Australia. Buckingham: Open Univerity Press.

Kimbell, R. (2005). Assessing design innovation. In L. Lindström (Ed.), Technology education in new perspectives: Research, assessment and curriculum development, festschrift for Witold Rogala (pp. 17-35). Retrieved from http://www.diva-portal.org/smash/get/diva2:697601/FULLTEXT01.pdf\#page=17. Accessed 14 March 2017.

Lawson, B. (2006). How designers think: The design process demystified. London: Routledge.

Lewis, T. (1993). Valid knowledge and the problem of practical arts curricula. Curriculum Inquiry, 23(2), $175-202$.

Lewis, T. (1999). Research in technology education-Some areas of need. Journal of Technology Education, $10(2), 41-56$.

Lewis, T. (2005). Coming to terms with engineering design as content. Journal of Technology Education, 16(2), 37-54.

Lewis, T., \& Gagel, C. (1992). Technological literacy: A critical analysis. Journal of Curriculum Studies, 24(2), 117-138.

Lewis, T., \& Zuga, K. F. (2005). A conceptual framework of ideas and issues in technology education. (Grant No. ESI-0138671). National Science Foundation. Retrieved from http://ctete.org/wp-content/uploa ds/2016/03/LewisZuga.ConceptualFramework1.pdf. Accessed 21 May 2017.

Lucas, B., \& Hanson, J. (2016). Thinking like an engineer: Using engineering habits of mind and signature pedagogies to redesign engineering education. International Journal of Engineering Pedagogy, 6(2), 4-13.

Lucas, B., Hanson, J., \& Claxton, G. (2014a). Thinking like an engineer: How to cultivate engineering habits of mind in schools, colleges and universities. London, England: Centre for Real-World Learning at the University of Winchester and Royal Academy of Engineering.

Lucas, B., Hanson, J., \& Claxton, G. (2014b). Thinking like an engineer: Implications for the education system. Royal Academy of Engineering. Retrieved from http://www.raeng.org.uk/publications/reports/thinkinglike-an-engineer-implications-summary. Accessed 20 February 2017.

Maslow, A. H. (1987). Motivation and personality. New York: Harper and Row.

MATSEC. (2017a). Matsec examinations board, University of Malta. Retrieved from February 20, 2017 https:// www.um.edu.mt/matsec.

MATSEC. (2017b). Sec 33 design and technology syllabus. Retrieved from April 1, 2017 https://www.um.edu. mt/_data/assets/pdf_file/0007/294307/SEC33.pdf.

MATSEC. (2017c). Sec 37 engineering technology syllabus. Retrieved 1st April, 2017, from https://www. um.edu.mt/_data/assets/pdf_file/0005/292397/SEC37.pdf.

MATSEC. (2018). Sec 33 design and technology syllabus. Retrieved from March 6, 2018 https://www.um.edu. mt/_data/assets/pdf_file/0007/294307/SEC33.pdf. 
Middleton, H. (Ed.). (2008). Researching technology education: Methods and techniques. Rotterdam: Sense Publishers.

Ministry for Education and Employment. (2012). A national curriculum framework for all. Retrieved from https ://education.gov.mt/en/Documents/A\%20National\%20Curriculum\%20Framework\%20for\%20All\%20-\%20 2012.pdf. Accessed 2 February 2017.

Ministry for Education and Employment. (2016a). Learning outcomes framework (ESF project 1.228). Retrieved from http://www.schoolslearningoutcomes.edu.mt/en/pages/about-the-framework. Accessed 22 January 2017.

Ministry for Education and Employment. (2016b). My journey: Achieving through different paths: Equitable quality education for all. Retrieved from http://www.myjourney.edu.mt/wp-content/uploads/2017/02/MYJOURNEY-BOOKLET-WEB-UPLOAD-24FEB17.pdf. Accessed 26 October 2017.

Ministry of Education. (1999). Creating the future together: National minimum curriculum. Retrieved from http://www.ibe.unesco.org/curricula/malta/mm_alfw_1999_eng.pdf. Accessed 2 February 2017.

Mitcham, C. (1994). Thinking through technology: The path between engineering and philosophy. Chicago: The University of Chicago Press.

Morgan, R., Jones, L., \& Barlex, D. (2013). New principles for design and technology in the national curriculum. Education for Engineering. Retrieved from http://www.solutions4schools.org.uk/site/module_publi cations/RAeng_E4E_Final_Report_DT_Curriculum.pdf. Accessed 8 May 2014.

Navarro, C., \& Pule', S. (2015). Visions for technology education in Malta, brief history and current issues. In Paper presented at the Proceedings of the PATT Conference on Plurality and Complementarity of Approaches in Design and Technology Education, Marseille, France.

NGSS Lead States. (2013). Next generation science standards: For states, by states. Washington, DC: The National Academies Press. Retrieved from http://www.nextgenscience.org/. Accessed 23 May 2017.

O’Sullivan, G. (2013). Design and technology education: Vocational or academic? A case of yin and yang. In G. Owen-Jackson (Ed.), Debates in design and technology education (pp. 74-85). Oxford: Routledge.

Petrina, S. (1994). Curriculum organization in technology education: A critique of six trends. Journal of Industrial Teacher Education, 31(2), 44-69.

Petrina, S. (1998). The politics of research in technology education: A critical content and discourse analysis of the journal of technology education, volumes 1-8. Journal of Technology Education, 10(1), $27-57$.

Petrina, S. (2000). The politics of technological literacy. International Journal of Technology and Design Education, 10(2), 181-206.

Rossouw, A., Hacker, M., \& de Vries, M. J. (2011). Concepts and contexts in engineering and technology education: An international and interdisciplinary delphi study. International Journal of Technology and Design Education, 4(21), 409-424.

Savage, E. N. (2002). A conceptual framework for technology education: A historical perspective. The Journal of Technology Studies, 28(2), 98-100.

Savage, E. N., \& Sterry, L. (1990a). A conceptual framework for technology education. Reston: International Technology Education Association.

Savage, E. N., \& Sterry, L. (1990b). A conceptual framework for technology education part 2. Technology Teacher, 50(2), 7-11.

Textalyser [computer software]. (2004). Free, online, statistical text analysis program (Version V 1.05). Retrieved from http://textalyser.net/index.php?lang=en. Accessed 1 February 2018.

Williams, P. J. (2002). Processes of science and technology: A rationale for cooperation or separation. In Paper presented at the PATT 12 conference: Technology education in the curriculum: Relationships with other subjects, Columbus, OH. Retrieved from https://www.iteea.org/File.aspx?id=85931\&v=7b3fdf3f. Accessed 14 December 2007.

Williams, P. J. (2009). Technological literacy: A multliteracies approach for democracy. International Journal of Technology and Design Education, 19(3), 237-254.

Williams, P. J. (2013). Research in technology education: Looking back to move forward. International Journal of Technology and Design Education, 23(1), 1-9.

Williams, P. J. (2015). Vocational and general technology education. In P. J. Williams, A. Jones, \& C. Buntting (Eds.), The future of technology education (pp. 201-216). Singapore: Springer.

Williams, P. J. (2016). Research in technology education: Looking back to move forward... Again. International Journal of Technology and Design Education, 26(2), 149-157.

Williams, P. J., \& Barlex, D. (Eds.). (2017). Contemporary research in technology education: Helping teachers develop research-informed practice. Singapore 189721. Singapore: Springer.

Williams, P. J., Jones, A., \& Buntting, C. (Eds.). (2015). The future of technology education. Singapore: Springer.

Zuga, K. F. (1989). Relating technology education goals to curriculum planning. Journal of Technology Education, 1(1), 34-58. 
Zuga, K. F. (1997). An analysis of technology education in the United States based upon an historical overview and review of contemporary curriculum research. International Journal of Technology and Design Education, 7(3), 203-217. 